\title{
Reframing Parental Involvement in Education: Unboxing the Stiffness of the Indonesian 2013 Curriculum for Character Building
}

\author{
Bujang Rahman \\ University of Lampung \\ Bandar Lampung, Indonesia
}

Abdurrahman

University of Lampung

Bandar Lampung, Indonesia

\begin{abstract}
An increasingly multidisciplinary research on parental involvement in education has been captured quite well in the body of literature discussing factors affecting students' learning outcomes. Parental involvement in education is believed to benefit both students' academic and non-academic learning outcomes. Parental involvement in improving their children education has assisted children in enhancing their competence across school's levels. The current paper is intended to frame parental involvement in education, to identify their expectations in their involvement in education, as well as to reframe their involvement in the context 2013 Curriculum (hereafter K-13) in Indonesia. Approximately thirty schools in Kota Metro, Lampung, Indonesia were identified in terms of parental involvements in those schools. The subject of the research comprised of parents, school committee, as well as headmasters that were explored to share their ideas on the parental involvement and expectations at school activities. The finding suggest that parental involvement at schools had been previously restricted to passive involvement, while expecting to be active one, and has to be reframed to a more active involvement in enhancing students cognitive and affective outcomes. Further forms of parental involvement in education in intervening students' learning outcomes were proposed.
\end{abstract}

Keywords---Parental involvement; Curriculum 2013; learning outcome; character building.

\section{INTRODUCTION}

Studies on parent involvement in education have gained considerable interest among researchers focusing on the area and its impacts on student learning outcomes [1-4]. Research findings in this area have indicated that parent involvement in the education process at school plays important roles in assisting learners to gain better achievements as well as to have better behaviors as the result of the education process. Parent involvement has also been found to influence learners 'social activities in that their existence in the community could be well managed and even positively influential. Within the framework of parent involvement, learners could explore their talents, abilities, and attitudes in response to the community's adaptation and gain outstanding achievements [5]. In short, parent involvement in education has been positively associated with indicators of student achievement, either academic achievements, behavioral or social competence.

Parent involvement in education can be viewed in different patterns of involvement such as home-based pattern (e.g., helping with homework), school-based pattern (e.g., attending school events), as well as a community-based pattern (a multicontrolled children activity in the community outside home and school). Those involvement patterns have been acceptably associated with indicators of the success of education at school, such as lower rates of retention in grade [6-8], lower drop-out rates [9-11], higher on-time high school graduation rates [3, 12, 13], and higher achievement at school $[1,2,4]$.

Realizing the importance of parent involvement in education, the Indonesian national curriculum, or Kurikulum 2013 (abbreviated K-13), has to sufficiently incorporate parent involvement in the education process utilizing K-13. Being somewhat a newly regulated curriculum, not few parents are actually in doubt, apart from the school caretakers such as principals, teachers, teacher educators, with the implementation of K-13. Negative stereotypes about the policy, essence, and implementation of $\mathrm{K}-13$ are quite often found and are unelectable in both formal and informal educational talks. Those different perspectives among parents in perceiving of what is intended by the government about the K-13 thing will lead to different responses and are likely to end up with the uncertainty of their children achievement at school.

Parents' anxiety about their children achievement at schools was not without reasons. As long as 3 years of the K-13 implementation, this new curriculum is still undergoing some significant reconstruction at the conceptual and implementation level. Therefore, it is no doubt that currently, not all schools have implemented the K-13. In addition, the government itself leaves the school administrators with a choice whether or not to implement this new curriculum due to its being quite "unprepared"; a school may implement K-13, or return to the previous curriculum (Curriculum 2006). This is what some parents had initially protested against the government in the K- 
13 policy. Parents believed that their involvement in education was restricted in this context. They did not have access to collaboratively join with schools or the government to design the curriculum that is intended for their children education. This is presumably caused by the use of a formerly centralized curriculum, in which they have been accustomed to that, which has been an old tradition since Indonesian independence in 1945. So far, their involvement has been just merely associated with school financial matter, tended to be passive, and lack of contact with schools.

Such framework of parent involvement in education has to be revisited and reframed. Let alone, the K-13 itself, if thoroughly comprehended, opens a wider window for parents to be more involved in the education of their children. A simple indication that is easily captured in relation to parental involvement in education relies on the standard competence, which has to be achieved in each stage of learning. The standard of student learning outcomes within K-13 framework comprises three types of competence, cognitive, affective, and psychomotor domains. These three domains cannot be easily achieved without the existence of parent involvement at schools, especially in the formation of students expected behaviors of attitude in relation to the affective domain. This paper attempts to give a clearer picture of reframing parental involvement in education by analyzing and extracting parents' current position in $\mathrm{K}-13$, then reframing their position followed by a review of related literature. At the later stage, the current paper will show empirical data about what actually parents expect in relation to their involvement in the education of their children.

The empirical study was conducted in thirty schools in Kota Metro, as the benchmark of the City of Education in Lampung Province, Indonesia. The subject of the research comprised of parents, school committee, as well as headmasters. They were explored to share their ideas on the parental involvement and expectations at school activities. To understand the framework of parental involvement in education, a summary of related research would be given for the sake of deeper understanding of the parental forms of involvement both at the school and at home. Subsequently, a re-framed model of parental involvement in education in the context of K-13 in Kota Metro, Lampung, and Indonesia would be discussed thoroughly. This paper will provide unique insights about one aspect of student learning outcome factors within the complexity of the K-13 implementation in Indonesia, which in turn bearing a distinctive position of the Indonesian national curriculum in the global context.

\section{METHODS}

\section{A. Parents' Involvement Framework}

For several years, a number of studies have been dedicated to the importance of parent involvement in education [14-16]. However, such a research focus in identifying parent involvement in education at schools has been up and down. Most research conducted on parent involvement in education has also been merely associated with student cognitive achievement [17], rather than affective domains of children's development, such as attitude and motivation. This phenomenon is likely to be attributed to parents' common sense of the academic success in nature; getting higher grades at school [18]. This condition is what most people believe about the attribution of students' success at school. Teachers and parents, on the other hand, may collaborate in discussing students' affective competence achievement in the classroom as well, since effective competence has to be achieved as well in relation to the indicators of the learning success in the framework of K-13 curriculum.

Parent involvement in education has been understood as parent engagement with children in an educational context, both in the home and school settings where they are meant to support their children's educational progress. Indicators of parent involvement could be in the form of quality and quantity of their communication with teachers as well as participation in school functions and activities [19-21]. Other indicators of parent involvement can also be their values and attitudes regarding education and the aspirations they hold for their children [22]. Although values and attitudes may not directly influence academic outcomes, they may enhance academic achievement indirectly by promoting children's motivation and persistence in challenging educational tasks [23].

\section{B. Reframing Parent Involvement: More than Just Cognitive Competence}

Many studies on parent involvement have been commonly focused on connections between parent involvement and academic achievement, especially cognitive achievement. Such studies usually have been tended to the parent involvement and its impact on students' cognitive achievement, as what is mostly connected is the students' achievement which is merely cognitive [24-26]. Such studies, parent involvement, and academic achievement reflect the common practice of considering parent involvement as only focusing on cognitive achievements as the educational outcomes rather than effective and psychomotor [1]. Findings of those studies suggested that differences in levels of parent involvement in education may likely result in the delay of children's literacy skills, and on the other hand, increasing the level parent involvement during school would be positively associated with literacy growth. In other words, parent involvement has been commonly considered as a circumstance for promoting learners' academic performance apart from other factors [27].

However, what needs to be reframed in relation to parent involvement should not only be just enhancing learners' cognitive achievement, rather learners' behavior at home and in the classroom when socializing with other learners should also be taken into further account. With this stake, parents and teachers need to work together to enhance learners' behavioral competence that would be best approached by collaborative framed activities between parents and teachers [28]. At school, the teacher may already have a set of activities and assessments in measuring the learners' behaviors and that frame could be easily captured and implemented. However, since behavior is dynamic, and for the sake of forming good habit among the learners, those behavioral activities at school could be maintained at home when they have more time with their parents. This mode of involvement could be captured in the two modes of involvement: cognitive and behavioral activities. 
On the other hand, a growing literature has also indicated the benefits of parent involvement in improving students' social competence $[1,3,28]$. Parent involvement in relation to the learners' social competence may not be easily identified. Its impact may not be directly influencing the students' academic achievement, however, this competence may be in support of the learners affective or behavioral competence, by making the learners be more motivated and having a good attitude that builds their confidence in the teaching-learning process as the effect of their being confident in the society. For example, when learners are in contact with the society or the community where they have been raised outside a home, they usually bring what they have achieved from home and school with parent supports. They could socialize better with the people in the community and they could even offer some influential ideas, talent, competence, etc. they could be more adaptive to the community they exist.

The current paper was written partially utilizing data taken from the research and development [29] carried out under the research grant of Directorate General for Higher Education, Ministry of Education, Indonesia in 2015. The selected data have not been used for publication elsewhere. The research grand theme was the implementation school good governance in thirty schools in Metro city, Lampung, Indonesia. The research was designed to explore how teachers, headmasters, school committee, as well as parents have established a relationship in implementing good governance at school. Subsequently, how such establishment promotes students' achievements were addressed. The subjects of the research were teachers, parents, and headmasters of those schools. In the early step, education practitioners, especially the principals, teachers, school committees, school superintendent, and the Department of Education were invited to come to introduce a model of good governance through strengthening the role of the primary school committee.

As a part of the grand research discussed above, school committees in Metro City where most of the participants were parents appointed as the member of the school committee. Focused Group Discussion was carried out to gather information about their expectations on how teacher-parent relationship should be built. The result of the focused group discussion was formulated in a structured description. In the second step of the research, representative parents were invited to a school hub, including teachers and headmasters. This meeting was intended to seek for information about their current condition and expectation about how to achieve an effective school where parents and school have good ties. The data of both research agenda will be elaborated in an exploratory way in a matrix displaying current conditions and expectations of the teacher-parent relationship.

\section{RESULT AND DISCUSSION}

As widely understood, parents' attitudes, behaviors, and activities relate to children's education influence students' learning and educational success. In other words, parental involvements in improving their children education have assisted children in enhancing their competence. This study was particularly conducted in Kota Metro, as the benchmark of the City of Education in Lampung Province, Indonesia. Forms and models of parental involvement in education in Kota Metro, Lampung Province have been found to be set in a fashioned way in comparison to other such districts. Although not all parents have been involved in the education process of their children, their involvements have to be further developed. The result of the focused group discussion between school committee, teachers, parents, and headmasters is discussed as follows.

TABLE I. STRUCTURAL FRAME OF PARENT INVOLVEMENT

\begin{tabular}{|c|c|c|c|}
\hline No. & Mode & Statements & Descriptions \\
\hline \multirow[t]{3}{*}{1} & At School & $\begin{array}{c}\text { Curriculum Need } \\
\text { Analysis }\end{array}$ & $\begin{array}{l}\text { Parents feel the } \\
\text { insufficient } \\
\text { availability of } \\
\text { involvement in } \\
\text { identifying what the } \\
\text { school needs for the } \\
\text { affectivity K-13 } \\
\text { implementation for } \\
\text { maximum learning } \\
\text { outcome }\end{array}$ \\
\hline & & $\begin{array}{l}\text { Involvement in } \\
\text { Fulfilling the } \\
\text { Necessities }\end{array}$ & $\begin{array}{l}\text { Parents feel to have } \\
\text { been involved } \\
\text { supporting the K- } \\
\text { 13program, one of } \\
\text { them is in supplying } \\
\text { facilities and } \\
\text { infrastructure for the } \\
\text { success of the } \\
\text { teaching-learning } \\
\text { process. }\end{array}$ \\
\hline & & $\begin{array}{c}\text { Involvement in } \\
\text { Learning Process at } \\
\text { School }\end{array}$ & $\begin{array}{l}\text { Parents have not } \\
\text { been fully involved } \\
\text { in learning with the } \\
\text { K-13, but there are } \\
\text { already some } \\
\text { activities undertaken } \\
\text { by the school } \\
\text { committee in order } \\
\text { to involve the } \\
\text { participation of } \\
\text { parents in the } \\
\text { learning-13, such as } \\
\text { pesantren kilat, } \\
\text { family day, and } \\
\text { entrepreneurship }\end{array}$ \\
\hline 2 & At Home & $\begin{array}{l}\text { Involvement in } \\
\text { learning at home } \\
\text { (Academic) }\end{array}$ & $\begin{array}{l}\text { The role and } \\
\text { involvement of } \\
\text { parents outside the } \\
\text { school is to } \\
\text { supervise the } \\
\text { children's learning } \\
\text { activities at home } \\
\text { like to remind their } \\
\text { children to do their } \\
\text { homework and } \\
\text { encourage their } \\
\text { children to } \\
\text { summarize each } \\
\text { lesson they have } \\
\text { passed. In the } \\
\text { implementation, } \\
\text { parents have always } \\
\text { been reminded by } \\
\text { the teacher through } \\
\text { SMS to accompany } \\
\text { their children } \\
\text { learning activities at } \\
\text { home. }\end{array}$ \\
\hline
\end{tabular}




\begin{tabular}{|c|c|c|l|}
\hline & $\begin{array}{c}\text { Involvement in } \\
\text { Learning Process at } \\
\text { Home (non- } \\
\text { academic) }\end{array}$ & $\begin{array}{l}\text { Parents are } \\
\text { observing their } \\
\text { children activities at } \\
\text { home related to } \\
\text { learning, for } \\
\text { example how to } \\
\text { clean the bedroom, } \\
\text { maintain a healthy } \\
\text { body, observing } \\
\text { social issues, etc. }\end{array}$ \\
\hline 3 & $\begin{array}{l}\text { In the } \\
\text { Community }\end{array}$ & $\begin{array}{l}\text { The intensity of } \\
\text { communication } \\
\text { between teachers } \\
\text { Involvement } \\
\text { and parent should be } \\
\text { increased to achieve } \\
\text { the success of the } \\
\text { children's learning } \\
\text { by using K-13. }\end{array}$ \\
\hline
\end{tabular}

Within the frame of parent involvement at school, the role parent involvement has been associated with role construction for the involvement in school. Parent role construction here covers a sense of individual or collective responsibility for the learners' educational outcomes and the expectations about how the involvement should be designed in supporting the learners' outcome. Parent role construction has been understood as their beliefs about what they should do for their children's education and how they would do that. Such mode of involvement is affected by their beliefs about how children should be educated, what they should do to motivate their children, and what they should do for the success of their children at school. Such mode of involvement is also influenced by the expectations of the learners themselves and groups about the parents' responsibilities regarding their children education.

The foundation of K-13 in Indonesian education system is in fact on the bases of competency-based curriculum, formerly known as Kurikulum Berbasis Kompetensi (KBK). The idea of such curriculum is that the learning process should be, in whatever way, addressed to the attainment of a set of competence stipulated in the curriculum. The design of the teaching-learning process, assessment method, as well as content selection, should be all oriented to the attainment of the graduates' standard of competencies. In K-13, as one curriculum with the competency-based approach is meant to develop and prepare learners to have a degree of religious state, to have good characters, to be confident in the skills they have achieved, to be successful in learning, to be a responsible and positively behaved citizen. This framework clearly stated in the Government Regulation Number 32 The year 2013 about the National Standards of Education. With K-13, learners are targeted to own four core competencies, i.e. spiritual competence, social competence, cognitive competence as well as motoric competence (psychomotor). Table 2 shows how parents have been involved in the K-13 implementation and what expectations they have.

TABLE II. PARENTS OBSERVED EXPECTATIONS FOR THEIR INVOLVEMENT IN THE K13 IMPLEMENTATION

\begin{tabular}{|l|l|l|}
\hline Indicator & Current Attitudes & Teachers' \\
\hline
\end{tabular}

\begin{tabular}{|c|c|c|c|c|c|c|}
\hline & 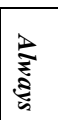 & 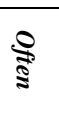 & $\frac{\sqrt[3]{2}}{\mathfrak{5}}$ & $\begin{array}{l}\overparen{8} \\
\stackrel{8}{2}\end{array}$ & $\frac{3}{9}$ & $\begin{array}{l}\text { Expectation of the } \\
\text { School } \\
\text { Regarding Attitudes }\end{array}$ \\
\hline $\begin{array}{l}\text { Habit of } \\
\text { timely } \\
\text { praying }\end{array}$ & $\begin{array}{l}\infty \\
\infty \\
a \\
a\end{array}$ & $\begin{array}{l}N \\
\infty \\
a \\
a\end{array}$ & $\begin{array}{l}n \\
\infty \\
\infty \\
0\end{array}$ & & & $\begin{array}{l}\text { The expectation of } \\
\text { parents to the school is } \\
\text { to make a program } \\
\text { which can make } \\
\text { students pray on time. }\end{array}$ \\
\hline $\begin{array}{l}\text { Showing } \\
\text { gratitude for } \\
\text { the God }\end{array}$ & $\underset{+\infty}{\stackrel{N}{a}}$ & $\stackrel{N}{a}$ & $\begin{array}{l}\text { un } \\
\text { in }\end{array}$ & & & $\begin{array}{l}\text { The expectation of } \\
\text { parents to the school is } \\
\text { to cultivate saying } \\
\text { 'thank you'as a form of } \\
\text { gratitude. }\end{array}$ \\
\hline $\begin{array}{l}\text { Good at } \\
\text { managing } \\
\text { time(balance } \\
\text { between } \\
\text { worship, } \\
\text { play, and } \\
\text { learn) }\end{array}$ & $\underset{\frac{N}{D}}{\stackrel{N}{D}}$ & $\begin{array}{l}u_{u}^{u} \\
\dot{d} \\
d\end{array}$ & $\begin{array}{l}1 \\
0 \\
0 \\
9\end{array}$ & & & $\begin{array}{l}\text { The expectation of } \\
\text { parents to the school is } \\
\text { to teach students to } \\
\text { organize a schedule of } \\
\text { activities well. } \\
\text { Whether the activities } \\
\text { at school or at home. }\end{array}$ \\
\hline $\begin{array}{l}\text { Obeying } \\
\text { Parents: } \\
\text { indicated by } \\
\text { a sense of } \\
\text { obedient and } \\
\text { respect }\end{array}$ & $\begin{array}{l}w \\
\dot{u} \\
a \\
a\end{array}$ & $\begin{array}{l}\stackrel{1}{N} \\
\infty \\
d\end{array}$ & $\begin{array}{l}\stackrel{n}{u} \\
\text { a }\end{array}$ & & & $\begin{array}{l}\text { The expectation of } \\
\text { parents to the school is } \\
\text { in order to cultivate } \\
\text { respect, such as to } \\
\text { smile, to greet, and } \\
\text { greetings. }\end{array}$ \\
\hline $\begin{array}{l}\text { Showing } \\
\text { behavior as a } \\
\text { result of daily } \\
\text { worships }\end{array}$ & $\frac{N}{+\infty}$ & $\begin{array}{l}4 \\
i \\
a\end{array}$ & $\begin{array}{l}\vec{i} \\
j^{2}\end{array}$ & $\begin{array}{l}\vec{i} \\
a^{9}\end{array}$ & & $\begin{array}{l}\text { The expectation of } \\
\text { parents to the school is } \\
\text { in order to motivate } \\
\text { students to make sense } \\
\text { of that learning as a } \\
\text { form of worship. }\end{array}$ \\
\hline $\begin{array}{l}\text { Showing } \\
\text { respect for } \\
\text { the elders and } \\
\text { showing love } \\
\text { to the } \\
\text { youngers. }\end{array}$ & $\begin{array}{l}\stackrel{a}{+} \\
\stackrel{i}{a}\end{array}$ & $\underset{+}{\stackrel{N}{a}}$ & $\begin{array}{l}\vec{A} \\
\dot{i} \\
d^{9}\end{array}$ & & & $\begin{array}{l}\text { The expectation of } \\
\text { parents to the school is } \\
\text { in order to cultivate } \\
\text { respect, such as to } \\
\text { smile, to greet, and } \\
\text { greetings. }\end{array}$ \\
\hline $\begin{array}{l}\text { Showing } \\
\text { discipline in } \\
\text { daily } \\
\text { responsibiliti } \\
\text { es at home } \\
\text { (cleaning and } \\
\text { making the } \\
\text { bed, toys, } \\
\text { clothing, and } \\
\text { the } \\
\text { environment } \\
\text { around the } \\
\text { rooms of the } \\
\text { house) }\end{array}$ & $\frac{N}{a}$ & $\begin{array}{l}\text { N } \\
\infty \\
\text { in } \\
\text { di }\end{array}$ & $\begin{array}{l}\stackrel{A}{N} \\
\infty \\
j\end{array}$ & $\begin{array}{l}v \\
i \\
a^{9}\end{array}$ & & $\begin{array}{l}\text { The expectations of } \\
\text { parents to the school is } \\
\text { that the schools teach } \\
\text { students to motivate } \\
\text { and discipline in } \\
\text { performing the duty at } \\
\text { home. }\end{array}$ \\
\hline $\begin{array}{l}\text { Showing } \\
\text { discipline:stu } \\
\text { dying } \\
\text { independentl } \\
\text { y }\end{array}$ & $\begin{array}{l}\stackrel{1}{N} \\
\infty \\
0 \\
0\end{array}$ & $\frac{N}{d}$ & $\begin{array}{l}N \\
\infty \\
i n \\
j\end{array}$ & $\begin{array}{l}v \\
\dot{\omega} \\
\partial^{9}\end{array}$ & & $\begin{array}{l}\text { Expectations of parents } \\
\text { to the schools to teach } \\
\text { more independent } \\
\text { attitude. Like for } \\
\text { example when the } \\
\text { teachers ks students to } \\
\text { repeat each work, not } \\
\text { cheating. }\end{array}$ \\
\hline
\end{tabular}




\begin{tabular}{|c|c|c|c|c|c|c|}
\hline $\begin{array}{l}\text { Being honest } \\
\text { in all } \\
\text { situations }\end{array}$ & $\begin{array}{l}\text { yl } \\
\text { dᄋ }\end{array}$ & $\begin{array}{l}\infty \\
\infty \\
i \\
0 \\
0\end{array}$ & $\begin{array}{l}\overrightarrow{\vec{H}} \\
\mathrm{i} \\
\mathrm{j}\end{array}$ & $\begin{array}{l}v \\
i \\
j\end{array}$ & & $\begin{array}{l}\text { Expectations of parents } \\
\text { to the school so that } \\
\text { there is a system of } \\
\text { communication } \\
\text { between parents and } \\
\text { teachers. By doing so } \\
\text { can help parents to } \\
\text { know the problems } \\
\text { experienced by } \\
\text { students. }\end{array}$ \\
\hline $\begin{array}{l}\text { Responsible } \\
\text { for all given } \\
\text { obligations }\end{array}$ & $\begin{array}{l}\stackrel{N}{D} \\
a^{9}\end{array}$ & $\begin{array}{l}\stackrel{w}{\sim} \\
\dot{y} \\
0\end{array}$ & $\begin{array}{l}\infty \\
\infty \\
i \\
0 \\
0\end{array}$ & $\begin{array}{l}\text { N } \\
j^{2}\end{array}$ & $\begin{array}{l}\text { in } \\
a^{9}\end{array}$ & $\begin{array}{l}\text { Expectations of parents } \\
\text { to the school so that } \\
\text { students are given each } \\
\text { task, such as picket } \\
\text { class. So they have a } \\
\text { sense of responsibility } \\
\text { towards their } \\
\text { respective duties. }\end{array}$ \\
\hline $\begin{array}{l}\text { Demonstratin } \\
\mathrm{g} \text { a sense of } \\
\text { caring }\end{array}$ & $\begin{array}{l}N \\
\infty \\
\text { in } \\
d^{2}\end{array}$ & $\begin{array}{l}\text { y } \\
0 \\
0\end{array}$ & $\begin{array}{l}\sim \\
\dot{u} \\
0^{\circ}\end{array}$ & & & $\begin{array}{l}\text { Expectations of parents } \\
\text { to the school to teach } \\
\text { social attitudes to } \\
\text { others. For example, } \\
\text { when a friend invited } \\
\text { to visit the sick. }\end{array}$ \\
\hline $\begin{array}{l}\text { Showing } \\
\text { respect for } \\
\text { differences in } \\
\text { age, and } \\
\text { facilities are } \\
\text { given by their } \\
\text { parents of } \\
\text { among } \\
\text { members of } \\
\text { the family }\end{array}$ & 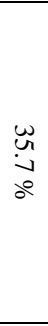 & $\begin{array}{l}\vec{t} \\
\text { i } \\
\text { do }\end{array}$ & $\begin{array}{l}\hat{N} \\
\infty \\
\infty \\
0\end{array}$ & $\begin{array}{l}\vec{w} \\
j^{9}\end{array}$ & & $\begin{array}{l}\text { Expectations of parents } \\
\text { to the schools to teach } \\
\text { to appreciate the } \\
\text { differences in nature, } \\
\text { age, and the facilities } \\
\text { provided. }\end{array}$ \\
\hline $\begin{array}{l}\text { Behaving } \\
\text { politely, } \\
\text { being } \\
\text { respectful, } \\
\text { and caring } \\
\text { for the guests } \\
\text { and } \\
\text { neighbors }\end{array}$ & $\frac{y}{i}$ & $\begin{array}{l}\sim \\
\stackrel{N}{+} \\
0\end{array}$ & $\begin{array}{l}\vec{A} \\
\dot{i} \\
j^{\circ}\end{array}$ & $\begin{array}{l}\vec{i} \\
j\end{array}$ & & $\begin{array}{l}\text { Expectations of parents } \\
\text { to the school to always } \\
\text { teach polite behavior. } \\
\text { For example, the } \\
\text { school held a } \\
\text { friendship with parents } \\
\text { and students so that } \\
\text { they can be one of } \\
\text { learning in teaching } \\
\text { polite behavior. }\end{array}$ \\
\hline $\begin{array}{l}\text { Showing } \\
\text { good social } \\
\text { communicati } \\
\text { on skills, } \\
\text { polite, and } \\
\text { friendly }\end{array}$ & $\begin{array}{l}N \\
\infty \\
a \\
0\end{array}$ & $\begin{array}{l}\stackrel{t}{N} \\
\infty \\
0\end{array}$ & $\begin{array}{l}n \\
\infty \\
a \\
0\end{array}$ & & & $\begin{array}{l}\text { Expectations of parents } \\
\text { to the school to always } \\
\text { teach good } \\
\text { communication skills } \\
\text { to others. For example, } \\
\text { by teaching them how } \\
\text { to express opinions } \\
\text { during learning } \\
\text { activities. }\end{array}$ \\
\hline $\begin{array}{l}\text { Demonstratin } \\
\text { g a caring } \\
\text { attitude } \\
\text { towards } \\
\text { cleaning the } \\
\text { house and the } \\
\text { neighborhood }\end{array}$ & $\begin{array}{l}\vec{F} \\
\text { in } \\
d^{9}\end{array}$ & 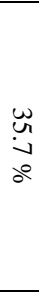 & $\begin{array}{l}\stackrel{w}{\sim} \\
\dot{y} \\
j o\end{array}$ & $\begin{array}{l}\vec{A} \\
\stackrel{\vec{A}}{\partial} \\
\overrightarrow{0}\end{array}$ & & $\begin{array}{l}\text { Expectations of parents } \\
\text { to the school so that } \\
\text { the school teaches } \\
\text { concern for hygiene, } \\
\text { such as holding } \\
\text { community service, } \\
\text { making the } \\
\text { slogan"throw trash in } \\
\text { the trash" }\end{array}$ \\
\hline
\end{tabular}

The table indicates the expectation of parents for the school to facilitate a program for building students attitudes. Their expectations varied, yet it was not difficult to spot some shared expectations for the schools. They ranged across the expectation of parents to the school to say 'thank you' as a form of gratitude, showing respect, such as to smile, to greet, and greetings, a system of communication between parents and teachers, etc.

Looking at parent expectations, they initially want the school to make a program, which can make students pray on time. This can be integrated with the school policy for the character building. One such activity is that the school members should accustom to saying 'thank you' as a form of gratitude. Another expectation of parents for the school is that learners have to be taught to organize a schedule of activities well whether the activities at school or at home. The expectation of parents to the school is in order to cultivate respect, such as to smile, to greet, and greetings could be planned for actions. Parents also expect the school to motivate students to make sense of that learning as a form of worship. These can be in the form of smile and greetings. Moreover, parents also expect that the schools teach students to motivate and make students discipline in performing the duty at home. Expectations of parents for the school can also capture that communication between parents and teachers should be well built.

Many studies have indicated that a good relationship between parents and the school offers many benefits for their student learning outcomes [30, 31]. Studies of parent and school (teacher) relationship have normally been categorized as parent-focused, the school focused, and partnership focused. They scrutinize the different roles, activities, and responsibilities of each side at the school or outside the school. These differences may be varied from, parents, teachers, school administrators, as well as stakeholders involved. For parents, they clearly have the primary responsibility for the education of their children at home. The involvement at school focuses normally signifies primary responsibility on the students' activities in the school. For teachers, for instance, they normally just have the responsibility of teaching and learning activities in the school. Parental involvements in improving their children education have assisted children in enhancing their competence.

\section{CONCLUSION}

Along the paper, it has been clearly understood that parent involvement in education has assisted children in enhancing their competencies across school's levels. In the context of the K-13 implementation, parent involvement has been just merely associated with school financial matter, tended to be passive, and lack of contact with schools. Such framework of parent involvement in education has to be revisited and reframed. K13 opens a wider window for parents to be more involved in the education of their children. The standard of student learning outcomes within K-13 framework comprises three types of competence, cognitive, affective, and psychomotor domains. These three domains cannot be easily achieved without the existence of parent involvement at schools, especially in the formation of students expected behaviors or attitude in relation to the affective domain. Reframing parental involvement in the position of K-13 has to be carried out in Indonesian education system for the betterment implementation of the curriculum. Further forms of reframing still open wider perspectives to search for the best model of parent involvement in the national curriculum framework. 


\section{REFERENCES}

[1] M. Castro, E. Expósito-Casas, E. López-Martín, L. Lizasoain, E Navarro-Asencio, J.L. Gaviria, Parental involvement on student academic achievement: A meta-analysis, Educational Research Review (EARLI), 14 (2015) 33-46.

[2] N. Gupta, R. Kumar, Parent Academic Involvement and Academic Achievement of Tenth Grade Students, Indian Journal of Applied Research (IJAR), 5 (2016).

[3] M. Hayakawa, M. Englund, M. Warner-Richter, A. Reynolds, Early parent involvement and school achievement: a longitudinal path analysis, NHSA Dialog, 16 (2013)

[4] R.B. McNeal Jr, Parent involvement, and student performance: the influence of school context, Educational Research for Policy and Practice (ERPP) 14 (2015) 153-167.

[5] M.J. Dufur, T.L. Parcel, K.P. Troutman, Does capital at home matte more than capital at school? Social capital effects on academic achievement, Research in Social Stratification and Mobility (RSSM), 31 (2013) 1-21.

[6] C.A. Griffith, J.W. Lloyd, K.L. Lane, M. Tankersley, Grade retention of students during grades $\mathrm{K}-8$ predicts reading achievement and progress during secondary schooling, Reading \& Writing Quarterly (RWQ), 26 (2010) 51-66.

[7] E.M. Ingoldsby, Review of interventions to improve family engagement and retention in parent and child mental health programs, Journal of Child and Family Studies (JCFS), 19 (2010) 629-645.

[8] S.-R. Ou, A.J. Reynolds, Grade retention, postsecondary education, and public aid receipt, Educational Evaluation and Policy Analysis (EEPA), 32 (2010) 118-139.

[9] S.C. Faircloth, J.W. Tippeconnic III, The dropout/graduation crisis among American Indian and Alaska Native students, (2010).

[10] K.L. Henry, K.E. Knight, T.P. Thornberry, School disengagement as a predictor of dropout, delinquency, and problem substance use during adolescence and early adulthood, Journal of youth and adolescence (JYA), 41 (2012) 156-166.

[11] F.P. Schargel, J. Smink, Strategies to help solve our school dropout problem, Routledge, 2014.

[12] J. Bryan, A. Young, D. Griffin, L. Henry, Preparing students for higher education: How school counselors can foster college readiness and access, Higher Education and Society. New York: Peter Lang, (2015) 2

[13] S.A. Crosby, T. Rasinski, N. Padak, K. Yildirim, A 3-year study of a school-based parental involvement program in early literacy, The Journal of Educational Research (JER), 108 (2015) 165-172.

[14] N. Choi, M. Chang, S. Kim, T.G. Reio, A structural model of parent involvement with demographic and academic variables, Psychology in the Schools, 52 (2015) 154-167.

[15] M.J. Fine, The second handbook on parent education: Contemporary perspectives, Elsevier, 2014

[16] M.J. Marschall, P.R. Shah, Linking the Process and Outcomes of Parent Involvement Policy to the Parent Involvement Gap, Urban Education, (2016) 0042085916661386
[17] W.H. Jeynes, A Meta-analysis the relationship between father involvement and student academic achievement, Urban Education, 50 (2015) 387-423

[18] M.T. Wang, S. Sheikh-Khalil, Does parental involvement matter for student achievement and mental health in high school?, Child Development, 85 (2014) 610-625.

[19] C. Gestwicki, Home, school, and community relations, Cengage Learning, 2015.

[20] L.-H. Ho, C.-L. Hung, H.-C. Chen, Using theoretical models to examine the acceptance behavior of mobile phone messaging to enhance parentteacher interactions, Computers \& Education (COMPEDU), 61 (2013) 105-114.

[21] C.V.R.F.i.E. Policy, Parents and teachers: Power and participation, Routledge, 2013.

[22] Y. Kim, M. Sherraden, J. Huang, M. Clancy, Child Development Accounts and parental educational expectations for young children: Early evidence from a statewide social experiment, Social Service Review (SSR), 89 (2015) 99-137.

[23] J. Núñez, N. Suárez, P. Rosário, G. Vallejo, A. Valle, J. Epstein Relationships between perceived parental involvement in homework, student homework behaviors, and academic achievement: differences among elementary, junior high, and high school students, Metacognition and learning, 10 (2015) 375-406.

[24] J. Fantuzzo, V. Gadsden, F. Li, F. Sproul, P. McDermott, D. Hightower A. Minney, Multiple dimensions of family engagement in early childhood education: Evidence for a short form of the Family Involvement Questionnaire, Early Childhood Research Quarterly (ECRQ), 28 (2013) 734-742.

[25] A. Gonzalez-DeHass, Preparing 21st Century Learners: Paren Involvement Strategies for Encouraging Students' Self-Regulated Learning, Childhood Education (CE), 92 (2016) 427-436.

[26] W.S. Grolnick, J.N. Raftery-Helmer, E.S. Flamm, Parent involvement in learning, International guide to student achievement, (2013) 101-103.

[27] S. Wilder, Effects of parental involvement on academic achievement: a meta-synthesis, Educational Review (CEDR), 66 (2014) 377-397.

[28] L.A. Dinnebeil, B.E. Sawyer, J. Logan, J.M. Dynia, E. Cancio, L.M Justice, Influences on the congruence between parents' and teachers ratings of young children's social skills and problem behaviors, Early Childhood Research Quarterly (ECRQ), 28 (2013) 144-152.

[29] J.W. Creswell, Research design: Qualitative, quantitative, and mixed methods approaches, Sage publications, 2013.

[30] T. Feiler, Oh The Places You'll Go: Does Student Involvement, Student Perception of Parent Involvement, and High School Academic Achievement Impact the Level of Higher Education Achievement? (2015).

[31] M. LaRocque, I. Kleiman, S.M. Darling, Parental involvement: The missing link in school achievement, Preventing School Failure, 55 (2011) 115-122. 